\title{
A Systematic Review of Factors Influencing Older Adults' Hypothetical Treatment Decisions
}

\author{
Martine T Puts, RN, PhD, ${ }^{1}$ Brianne Tapscott, RN, BScN, ${ }^{2}$ Margaret Fitch, RN, PhD, ${ }^{3}$ Doris Howell, $\mathrm{RN}, \mathrm{PhD}^{4,5}$ \\ Johanne Monette, MD, MSc, ${ }^{6}$ Doreen Wan-Chow-Wah, MD, ${ }^{7}$ Monika K Krzyzanowska, MD, MPH, ${ }^{8,9}$ Natasha B Leighl, MD, BSc, MSc, ${ }^{8,9}$ \\ Elena Springall, $\mathrm{MSC}^{10}$ and Shabbir M Alibhai, MD, MSc ${ }^{11}$
}

\begin{abstract}
1. Assistant Professor, Lawrence S Bloomberg Faculty of Nursing, University of Toronto, Toronto, Ontario, Canada; 2. Registered Nurse, Children's Hospital of Eastern Ontario, Ontario, Canada; 3. Expert Lead/Program Consultant, Lawrence S Bloomberg Faculty of Nursing, University of Toronto, Toronto, Ontario, Canada; 4. Associate Professor, Lawrence S Bloomberg Faculty of Nursing, University of Toronto, Toronto, Ontario, Canada; 5. RBC Chair Oncology Nursing, Department of Oncology Nursing, Princess Margaret Cancer Centre, Toronto, Ontario, Canada; 6. Assistant Professor and Geriatrician, Division of Geriatric Medicine, and Co-Director of McGill University/ Université de Montreal Solidage Research Group on Frailty and Aging, Jewish General Hospital, Montreal, Quebec, Canada; 7. Medical Director, Consultation Service for Senior Oncology Patients, Division of Geriatric Medicine, Jewish General Hospital, Montreal, Quebec, Canada; 8. Medical Oncologist, Department of Medical Oncology and Hematology, Princess Margaret Cancer Centre, University Health Network, Toronto, Ontario, Canada; 9. Associate Professor, University of Toronto, Toronto, Ontario, Canada; 10. Acting Coordinator of Resource Sharing, Gerstein Science Information Centre, University of Toronto Libraries, Toronto, Ontario, Canada; 11. Senior Scientist and Staff Physician, University Health Network and University of Toronto, Toronto, Ontario, Canada
\end{abstract}

\begin{abstract}
Purpose: Cancer affects mostly older adults and although research has shown that a significant proportion of seniors do not receive treatment, little is known about the reasons why. Therefore, we conducted a systematic review of reasons why older adults accept or decline cancer treatments. Design: Systematic review of studies reporting on hypothetical cancer treatment scenarios in older patients published between inception of 10 databases and February 2013. Results: Of 17,343 abstracts reviewed, a total of 12 studies were included (sample size 21 to 511). The willingness to be treated varied by the benefits of treatment (ranging from never to always accepting the treatment), the particular side effects of treatment, and previous treatments received/previous treatment experiences (those who were treated previously were more likely to accept the same treatment). Results showed conflicting findings with regard to the impact of age, education (those with lower/higher age/education wanting more benefits before accepting), and family situation (no effect/those who were single were less likely to accept). Conclusion: Willingness among older adults to be treated was most influenced by the extent of benefits and side effects as well as prior treatment experiences. However, little is known about treatment preferences of the oldest old, those with multimorbidity, and preferences for newer agents.
\end{abstract}

\section{Keywords}

Systematic review, geriatric oncology, cancer treatment, treatment decision-making, treatment preferences, treatment refusal

Disclosure: Martine T Puts, RN, PhD, Brianne Tapscott, RN, BScN, Margaret Fitch, RN, PhD, Doris Howell, RN, PhD, Johanne Monette, MD, MSc, Doreen Wan-Chow-Wah, MD, Monika K Krzyzanowska, MD, MPH, Natasha B Leighl, MD, BSc, MSc, Elena Springall, MSC, and Shabbir M Alibhai, MD, MSc have no conflicts of interest to declare. There were no publication charges associated with this article.

Acknowledgments: The authors would like to thank Mr D Stephens who has been involved as a patient representative in this review.

Open Access: This article is published under the Creative Commons Attribution Noncommercial License, which permits any noncommercial use, distribution, adaptation, and reproduction provided the original author(s) and source are given appropriate credit.

Received: January 16, 2015 Accepted: March 15, 2015 Citation: Oncology \& Hematology Review, 2015;11(1):19-33 DOI: 10.17925/OHR.2015.11.01.19

Correspondence: Martine T Puts, RN, PhD, Lawrence S Bloomberg, Faculty of Nursing, University of Toronto, 155 College Street, Suite 130, Toronto, Ontario, Canada M5T 1P8.

E: martine.puts@utoronto.ca

Support: This work was supported by a knowledge synthesis grant \# 119803 from the Canadian Institutes of Health Research to Martine T Puts, RN, PhD. Martine T Puts, RN, PhD is supported with a New Investigator Award from the Canadian Institutes of Health Research.

Cancer is a significant health problem in older persons. ${ }^{1}$ It is estimated that $42 \%$ of all incident cases and over $60 \%$ of mortality due to cancer occur in persons aged 70 and over. ${ }^{1,2}$ With the aging of the population there will be a considerable increase in the number of older adults diagnosed with cancer. ${ }^{1,2}$ Treatment decisions are based on preferences, estimation of the risks and benefits, and costs. An individual makes a trade-off between 
Figure 1: Flow Chart of Study Selection

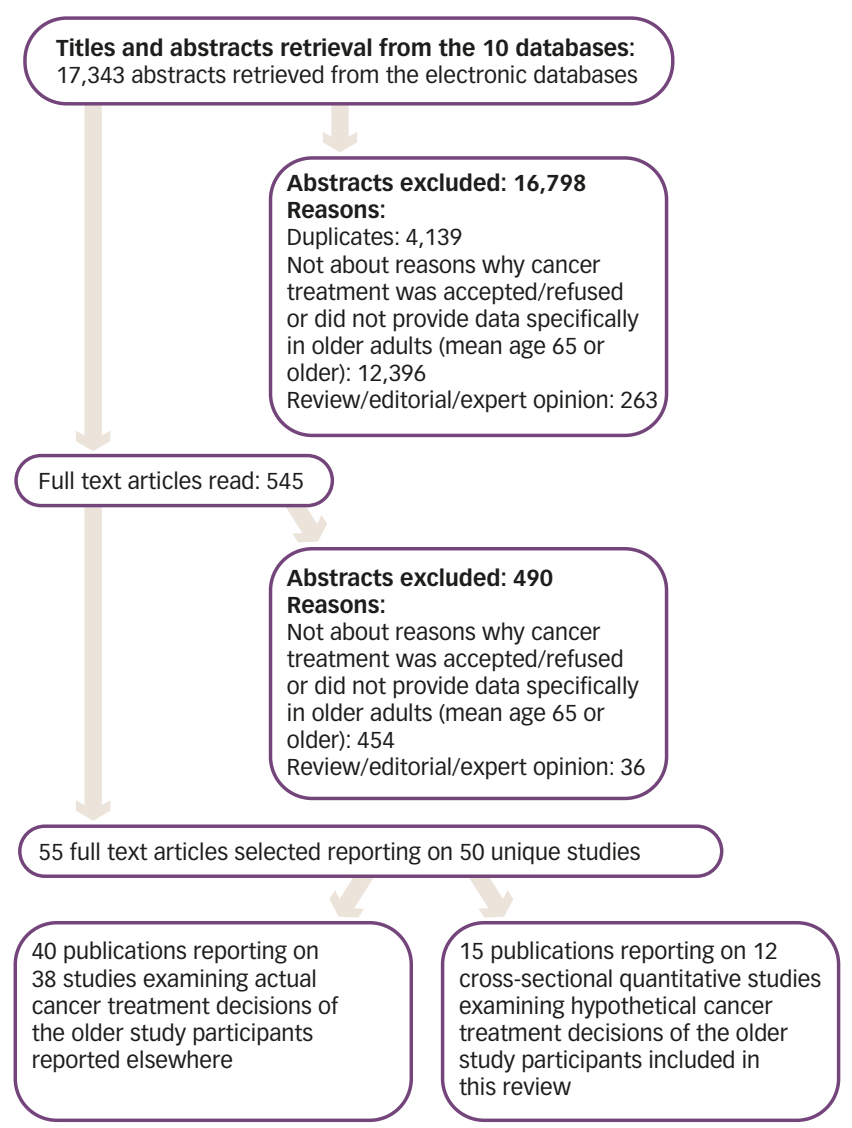

the benefits and harms. However, there is less known about risks and benefits for older adults as they are underrepresented in clinical trials, particularly the more frail older adults and those with comorbidities, ${ }^{3-7}$ which complicates treatment decision-making.

Underuse/nonreceipt of cancer treatment is commonly reported, and is more common in older adults. ${ }^{8-10}$ Recent studies have shown underuse in $46-49 \%$ of older patients. ${ }^{11-13}$ Undertreatment can lead to negative outcomes, such as increased cancer recurrence rate and poorer survival. Undertreatment has been most extensively studied in older women with breast cancer.8-10,14,15 Yood et al. ${ }^{15}$ reported a hazard ratio of 6.25 for breast cancer mortality in older women treated for less than 1 year with hormonal therapy compared with those treated for 5 years while Verkooijen et al. ${ }^{8}$ showed that older women who declined breast cancer surgery had a hazard ratio of breast cancer mortality of 2.1. Considering the impact of undertreatment on outcomes, it is important to understand for what reasons they would accept or decline cancer treatment. Several narrative reviews of treatment decision-making in older adults had been published ${ }^{16-18}$ but, until now, no systematic review has been performed. One way to study treatment decision-making is by studying preferences for a certain treatment based on studying the benefits and harms of one treatment compared with other alternatives, or about an individual's preference for a certain health state compared with a perfect health state. ${ }^{19}$

Therefore, we conducted a systematic review with the primary objective of synthesizing all factors influencing older adults' decisions to accept or decline cancer treatment proposed by their physicians. In particular, we were interested to determine if the factors influencing older adults' decisions to accept or decline cancer treatment varied by cancer stage, cancer type, cancer treatment, and age (younger-old [65-74] versus older-old $[75+])$. During the conduct of our systematic review on factors influencing the treatment decisions we noticed important methodologic differences between studies studying actual treatment decisions compared with studies using hypothetical treatment decisions. Additionally, examining hypothetical treatment decision-making removes the acute stresses of making decisions while facing a diagnosis of cancer. Therefore, we decided to report the results on actual situations and hypothetical scenarios separately. In this article, we will report on the results of studies examining hypothetical treatment decisions.

\section{Materials and Methods}

\section{Search Strategy and Selection Criteria}

This review was based on a systematic, comprehensive search of 10 databases from inception to February 2013 and was conducted by an experienced health sciences librarian (ES). A study (any type of design except case studies and editorials and reviews) was eligible for inclusion if it reported on reasons why older adults with cancer (i.e. mean age study population 65 years or over or if the study mean/median age was $<65$ but reported results on a subgroup analysis of older adults with a mean/median age $>65$ ) accepted or declined cancer treatment and was published in English, Dutch, French, or German.

The final studies included in this review were selected in two steps based on screening of the abstract and full-text review performed independently by two reviewers (MP and BT) (see Figure 1). For all articles for which no mean/median age was reported, we contacted the study authors to obtain details on age. If no response was received after at least three attempts, the article was not included.

\section{Data Abstraction}

The same reviewers who performed the article-selection process conducted data abstraction independently (MP and BT). The abstracted information included study design, aim of study, location of study, sampling method, source of data, recruitment type and timeline, characteristics of study participants, details on cancer diagnosis and treatment, details on how reasons for accepting/declining cancer treatment were collected, and details of statistical analysis, source of funding, and whether or not the authors had declared any conflict of interest. No meta-analysis was conducted as the studies were too heterogeneous with regard to study population and data collected.

\section{Quality Assessment}

Both quantitative and qualitative studies were included in the review. To determine the quality of the studies included in this review the same two reviewers scored the studies using the Mixed Methods Appraisal Tool (MMAT).20 The MMAT scoring system contains five types of mixed methods study components or primary studies, i.e. 1) qualitative; 2) quantitative randomized controlled trials; 3) quantitative nonrandomized; 4) quantitative descriptive; and 5) mixed methods with each with its own set of methodologic quality criteria based on existing published criteria. For each item the answer categories were 'yes', 'no,' or 'can't tell' followed by comments. We did not exclude 
Table 1: Quality Assessment using the Mixed Methods Appraisal Tool\#

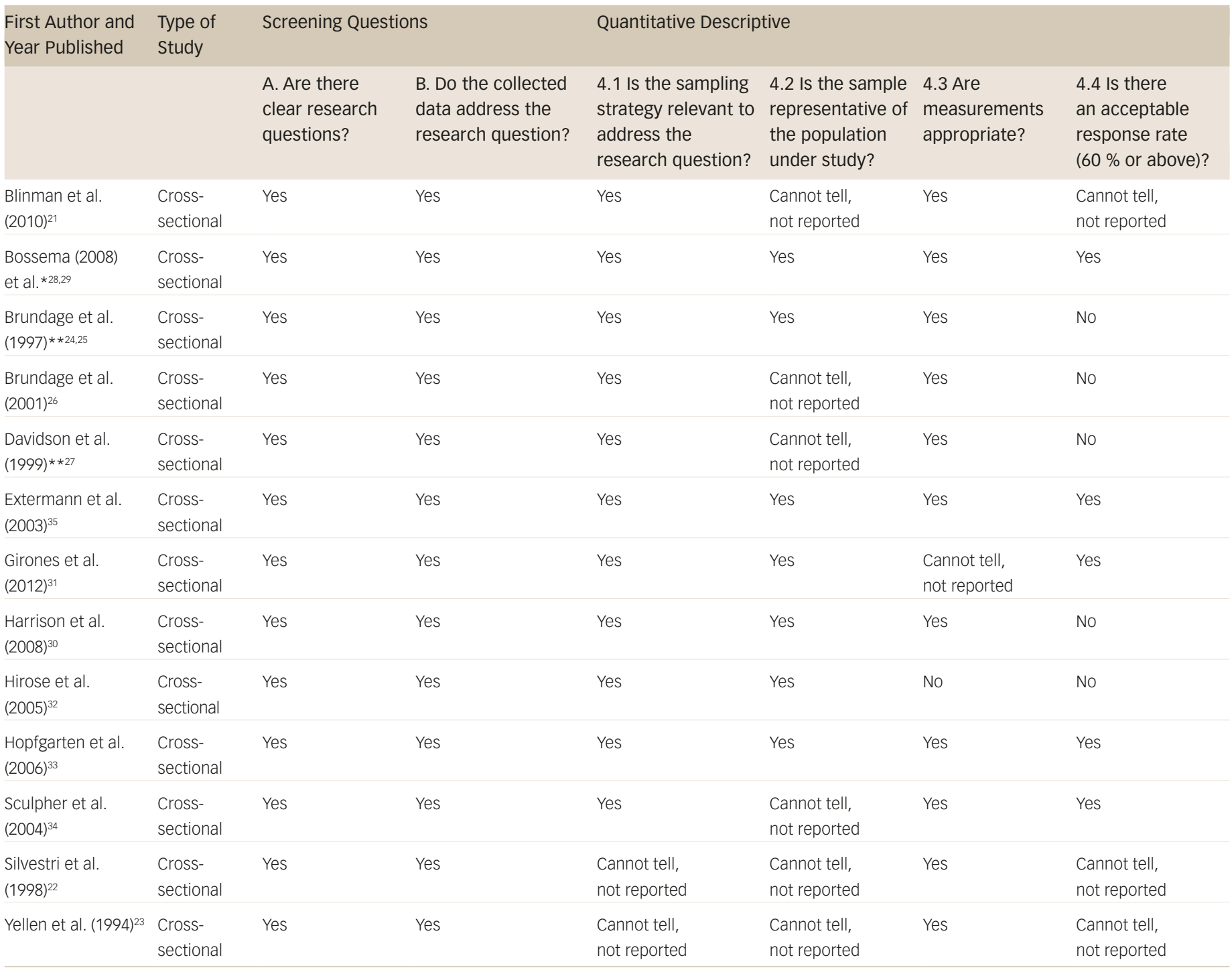

"None of the included studies were of another study design then quantitative descriptive, and thus these Mixed Methods Appraisal Tool criteria have been omitted from the table. *Papers report on the same study; **Papers report on the same study.

any study based on the quality assessment as we wanted to provide a comprehensive overview of all factors important to older adults reported in the literature.

\section{Results}

We reviewed 17,343 titles and abstracts for eligibility in the first step (see Figure 1) in which we selected 545 manuscripts for full text review. Of these 545,55 manuscripts reporting on 50 unique studies were selected; 40 publications reporting on 38 unique studies examined factors influencing the older adult's decision to accept or decline treatment examined the actual cancer treatment decision taken by the study participant and reported elsewhere (manuscript submitted). There were 15 manuscripts reporting on 12 unique studies that examined hypothetical treatment decisions and these are included in this review. All manuscripts were written in English.

\section{Quality Assessment}

The quality of the studies can be seen in Table 1. As many studies had been published some time ago when reporting standards were less clear, for most studies there were one or more aspects of the methodology used that were not described in sufficient detail and we tried to contact all study authors for more detail. Response rates were not reported for three out of 12 studies ${ }^{21-23}$ or were below $60 \%$ in two out of 12 studies, ${ }^{24-27}$ and the sampling strategy was not reported in two out of 12 studies. ${ }^{21,22}$ The hypothetical scenarios studied were generally well described. Most scenarios were reflective of actual treatment options (i.e. were realistic) for cancer patients at the time of the study according to the study authors. ${ }^{21,24,25,27-29}$

\section{Characteristics of the Included Studies}

See Table 2 for a description of included studies. Two studies were conducted in: Australia, ${ }^{21,30}$ the US, ${ }^{22,23}$ and Canada. ${ }^{24-27}$ One study was conducted in: 


\begin{tabular}{|c|c|c|c|c|}
\hline \multirow{2}{*}{\multicolumn{3}{|c|}{$\begin{array}{l}\text { First Author and Year Country Study Aim } \\
\text { Colorectal Cancer Treatment Decisions }\end{array}$}} & Sample Size and Response Rate & Mean/Median Age, SD (Range) \\
\hline & & \multicolumn{3}{|c|}{ Colorectal Cancer Treatment Decisions } \\
\hline Blinman et al. $(2010)^{21}$ & Australia & $\begin{array}{l}\text { To determine which survival benefit } \\
\text { would be judged as sufficient to } \\
\text { undergo adjuvant chemo in patients } \\
\text { with colorectal cancer }\end{array}$ & $\begin{array}{l}123 \\
N R\end{array}$ & Median age 65 \\
\hline Bossema $(2008) * 28,29$ & The Netherlands & $\begin{array}{l}\text { To investigate patients' preferences } \\
\text { for APR with a permanent stoma and } \\
\text { LAR with sphincter preservation }\end{array}$ & $\begin{array}{l}122 \\
91 \%\end{array}$ & $\begin{array}{l}\text { Mean age patients in the APR } \\
\text { group 68.6, SD 9.6; mean age } \\
\text { LAR group 67.9, SD } 10.3\end{array}$ \\
\hline Harrison $(2008)^{30}$ & Australia & $\begin{array}{l}\text { To understand patients' preferences } \\
\text { for different treatment options for } \\
\text { rectal cancer }\end{array}$ & $\begin{array}{l}103 \text { patients, } 87 \text { colorectal surgeons, } \\
97 \text { radiation oncologists and } 80 \text { medical } \\
\text { oncologists. Response rates: patients } \\
77 \% \text {, surgeons } 79 \% \text {, radiation oncologists } \\
47 \% \text {, and medical oncologists } 47 \%\end{array}$ & Mean age 65 (26-88) \\
\hline \multicolumn{5}{|c|}{ Lung Cancer Treatment Decisions } \\
\hline Brundage $(1997)^{\star * 24,25}$ & Canada & $\begin{array}{l}\text { What improvements in survival } \\
\text { probability would NSCLC patients like } \\
\text { to see before accepting toxic therapy? }\end{array}$ & $\begin{array}{l}56 \text { (22 lung, } 34 \text { prostate) } 33 \% \text { lung, } \\
\text { and } 39 \% \text { prostate }\end{array}$ & $\begin{array}{l}\text { Mean age: lung } 65 \text { years; } \\
69 \text { years for prostate }\end{array}$ \\
\hline Brundage $(2001)^{26}$ & Canada & $\begin{array}{l}\text { To examine how patients weigh both the } \\
\text { median survival time and 1-year survival } \\
\text { probability when considering a choice } \\
\text { between palliative cisplatin chemo with BSC } \\
\text { versus BSC alone for advanced NSCLC }\end{array}$ & $\begin{array}{l}60 \\
32 \%\end{array}$ & Mean age 68.3, SD 10.9 \\
\hline Davidson (1999)**27 & Canada & $\begin{array}{l}\text { To examine actual and desired levels of } \\
\text { involvement in treatment decisions for } \\
\text { lung cancer and information preferences } \\
\text { for treatment decision-making }\end{array}$ & $\begin{array}{l}21 \\
33 \%\end{array}$ & Mean age 65, SD 8 \\
\hline Girones (2012) $)^{31}$ & Spain & $\begin{array}{l}\text { To examine treatment preferences } \\
\text { and chemotherapy use in older lung } \\
\text { cancer patients }\end{array}$ & $\begin{array}{l}83 \\
100 \%\end{array}$ & Mean age 77, SD 5 \\
\hline Hirose $(2005)^{32}$ & Japan & $\begin{array}{l}\text { To determine how patients with lung } \\
\text { cancer weigh potential survival, } \\
\text { chemotherapy response rate and } \\
\text { symptom relief against the potential } \\
\text { toxicity of different chemotherapy option }\end{array}$ & $\begin{array}{l}73 \text { lung cancer patients and } 120 \text { with } \\
\text { other respiratory illnesses } 92 \% \text { for lung } \\
\text { cancer patients }\end{array}$ & $\begin{array}{l}\text { Median age lung cancer group } \\
66(40-80)\end{array}$ \\
\hline Silvestri $(1998)^{22}$ & US & $\begin{array}{l}\text { To determine how patients with lung } \\
\text { cancer value the trade-off between } \\
\text { the survival benefit of chemotherapy } \\
\text { and its toxicities }\end{array}$ & $\begin{array}{l}81 \\
N R\end{array}$ & $\begin{array}{l}\text { Age }<60: 38 \% \text {, age } 60-70: 37 \% \text {, } \\
\text { age }>70: 25 \%\end{array}$ \\
\hline \multicolumn{5}{|c|}{ Prostate Cancer Treatment Decisions } \\
\hline Hopfgarten (2006) ${ }^{33}$ & Sweden & $\begin{array}{l}\text { To examine prostate cancer patients } \\
\text { willingness to trade life for freedom from } \\
\text { therapy-induced long-term symptoms }\end{array}$ & $\begin{array}{l}511 \\
86.5 \%\end{array}$ & Mean age 71 (50-80) \\
\hline Sculpher $(2004)^{34}$ & UK & $\begin{array}{l}\text { To establish which attributes of } \\
\text { conservative treatments for early } \\
\text { prostate care are most important }\end{array}$ & $\begin{array}{l}129 \\
72 \%\end{array}$ & Mean age 70 SD 6.8 \\
\hline \multicolumn{5}{|c|}{ Chemotherapy Decisions in Mixed Populations } \\
\hline Exterman $(2003)^{35}$ & $\begin{array}{l}\text { US, } \\
\text { France }\end{array}$ & $\begin{array}{l}\text { To examine the willingness to be } \\
\text { treated with chemotherapy in older } \\
\text { American and French cancer and } \\
\text { noncancer patients }\end{array}$ & $\begin{array}{l}195 \\
\text { US cancer patients } 78 \%(n=62) \text {, } \\
\text { noncancer patients } 54 \%(n=43) \text {, } \\
\text { French cancer patients } 45 \%(n=36) \text {, } \\
\text { and noncancer patients } 68 \%(n=54)\end{array}$ & Mean age 77, (70-95) \\
\hline Yellen $(1994)^{23}$ & US & $\begin{array}{l}\text { 1) To examine if age impacted the } \\
\text { willingness to accept cancer treatment; } \\
\text { 2) To examine if older patients are } \\
\text { different from younger patients in } \\
\text { trading survival for quality of life }\end{array}$ & $\begin{array}{l}244 \text { (202 young (ages } x-y) \text {, } \\
42 \text { old (ages a-b) NR }\end{array}$ & Age >65 (65-83) \\
\hline
\end{tabular}

*Bossema 2008-1 and Bossema 2008-2 report on the same study; **Brundage 1997, Brundage 1998 and Davidson 1999 report on the same study. APR =abdominoperineal resection; $B S C=$ best supportive care; $L A R=$ low anterior resection; $N R=$ not reported; $N S C L C=$ non-small cell lung cancer; $S D=$ standard deviation. 
the Netherlands, ${ }^{28,29}$ Spain, ${ }^{31}$ Japan, ${ }^{32}$ Sweden, ${ }^{33}$ the UK, ${ }^{34}$ and one in both the US and France. ${ }^{35}$ All studies used a cross-sectional quantitative study design. Studies examined hypothetical treatment decisions for colorectal cancer, ${ }^{21,28-30}$ lung cancer, ${ }^{22,24-27,31,32}$ prostate cancer, ${ }^{33,34}$ or for chemotherapy in a mixed-study population. ${ }^{23,35}$ Sample sizes ranged between $21^{27}$ to $511,{ }^{33}$ mean age ranged from $65^{21,24,25,27}$ to 77 years. ${ }^{31,35}$

\section{Factors Influencing the Treatment Decisions}

Please see Table 3 for factors influencing the treatment decisions included in each study. Below we have summarized the findings for each cancer type treatment decision separately.

\section{Colorectal Cancer Treatment Scenarios}

In the three studies examining treatment decisions for colorectal cancer, all participants had been treated for colorectal cancer. Blinman et al. ${ }^{21}$ included 123 patients who had completed adjuvant chemotherapy for stage 2 to 3 colon cancer and asked the participants using four scenarios about their willingness to undergo treatment in exchange for increasing survival time or survival rate. They showed that $60 \%$ of the sample would choose chemotherapy for 1 additional month of life expectancy. Half of the sample would choose chemotherapy with small benefits (1 day), while a small proportion ( $<5 \%$ ) would never choose chemotherapy. Participants aged 75 and older and those with higher educational levels would only accept chemotherapy for greater benefits. Bossema et al. ${ }^{28,29}$ used the treatment trade-off and time trade-off method to examine the willingness to be treated with one of two surgical procedures, varying the risk for developing incontinence and permanent stoma as a result of the surgical procedure. All 122 participants had received surgery for stage 1-3 rectal cancer. The previously received surgery impacted the current choice: participants experiencing current incontinence were more willing to give up life years to avoid a permanent stoma (19\%) but not to avoid daily incontinence. Participants without a current stoma had a much stronger preference for the surgery that avoided a permanent stoma even if that meant incontinence monthly or daily. Similar findings were reported by Harrison et al., ${ }^{30}$ who reported that $65 \%$ of 103 participants, recruited postoperatively, were willing to give up $34 \%$ of their remaining life expectancy to avoid a stoma. Additionally, site of cancer (colon or rectal) had an effect on the choice, as did level of education, having previously received pre-operative treatment, and knowing someone who had undergone the treatment.

\section{Lung Cancer Treatment Scenarios}

Brundage et al. ${ }^{24,25}$ studied patients who had completed chemotherapy or chemo radiation or radiation treatment for lung $(n=22)$ or prostate $(n=34)$ cancer and solicited preferences for high- versus low- dose radiation and preference for high-dose radiation versus chemo radiation for locally advanced non-small cell lung cancer (NSCLC). They reported that there was a wide range in survival advantage thresholds required before accepting more aggressive treatments (range 0-80 \%) and a small number would always decline the aggressive treatments (4-16\%). There was no difference between the lung and prostate cancer patients and no factor (age, sex, education, or preferred role in decision-making) was associated with willingness to accept treatment. Davidson et al., ${ }^{27}$ reporting on the same study using the lung patients $(n=21)$, found that essential information needed to make the treatment decision included the regimen, the side effects, the survival information, and the effect of treatment on survival probability gains. Brundage et al. ${ }^{26}$ enrolled 60 patients treated for other cancers than lung and used the treatment trade-off method to compare when patients would choose best supportive care (BSC) (palliative radiation) versus BSC plus chemotherapy for advanced NSCLC. They showed that just over half would choose BSC plus chemotherapy for a 1-year survival advantage. Those who were older (correlation coefficient 0.30 ) or with no postsecondary education (correlation coefficient 0.31) had higher survival advantage thresholds before they would accept BSC plus chemotherapy. Girones et al. ${ }^{31}$ studied 83 patients with lung cancer (all stages) who were given the choice between four treatment options: two chemotherapy regimens with survival as the main goal (a mild regimen and an intensive regimen), one chemotherapy option with no survival benefit but aiming for symptom relief, and BSC. In contrast to all other studies described above, none of the patients had yet received cancer treatment. Girones et al. ${ }^{31}$ reported that over half of 83 patients choose treatment with survival as the treatment goal, only one-third chose BSC and only $12 \%$ chose symptom relief. Treatment choice was associated with age, performance status, depression and dementia, and frailty. Hirose et al. ${ }^{32}$ showed similar findings in 73 lung cancer patients who had been previously treated. They reported that the willingness of patients to accept toxicity for survival advantage varied: $19 \%$ would choose intensive and $21 \%$ would choose less-intensive chemotherapy if it would prolong life by 3 months; 73 \% would accept intensive chemotherapy for $70 \%$ chance of symptom relief. Although several factors were studied, only age was associated with the choice, with those aged 71-80 less likely to accept chemotherapy with smaller benefits compared with those $<70$ years. Similar findings, i.e. that willingness to accept more aggressive chemotherapy required larger median survival thresholds and that older patients had higher survival thresholds than younger patients, were reported by Silvestri et al. ${ }^{22}$ in a study of 81 advanced lung cancer patients who were previously treated with chemotherapy.

\section{Prostate Cancer Treatment Scenarios}

Hopfgarten et al. ${ }^{33}$ examined willingness to trade life expectancy (range 6 months to 5 years) to avoid long-term therapy-related side effects. They enrolled 511 prostate cancer patients of whom most had been previously treated with either surgery, radiation, and/or hormonal therapy. Most men were in the two extreme categories: they would either accept side effects for a small increase in survival probability (percentage of men ranging between $1 \%$ and $64 \%$ ) or they would not accept the side effects no matter what the survival benefit of treatment was (percentage of men ranging from $9 \%$ to $41 \%$ ). Age $70-80$ years, being single, having a lower educational level, and having a smaller social network were associated with a lower likelihood of accepting the treatment if it induced side effects. Sculpher et al. ${ }^{34}$ reported similar findings for 121 prostate cancer patients, some of whom had been treated with hormonal therapy. They reported that the willingness to undergo treatment was influenced by potential side effects and out-of-pocket costs (the greater the out-of-pocket costs, the less likely that patients preferred that treatment).

\section{Mixed Cancer Population Studies with Chemotherapy Decisions as the Focus}

Extermann et al. ${ }^{35}$ included 195 mixed cancer patients from France and the US and compared willingness to be treated with chemotherapy using an intensive treatment scenario and a milder treatment scenario. Forty-five percent of French patients had received prior chemotherapy versus $86 \%$ of American patients. Most patients in both countries would accept the 


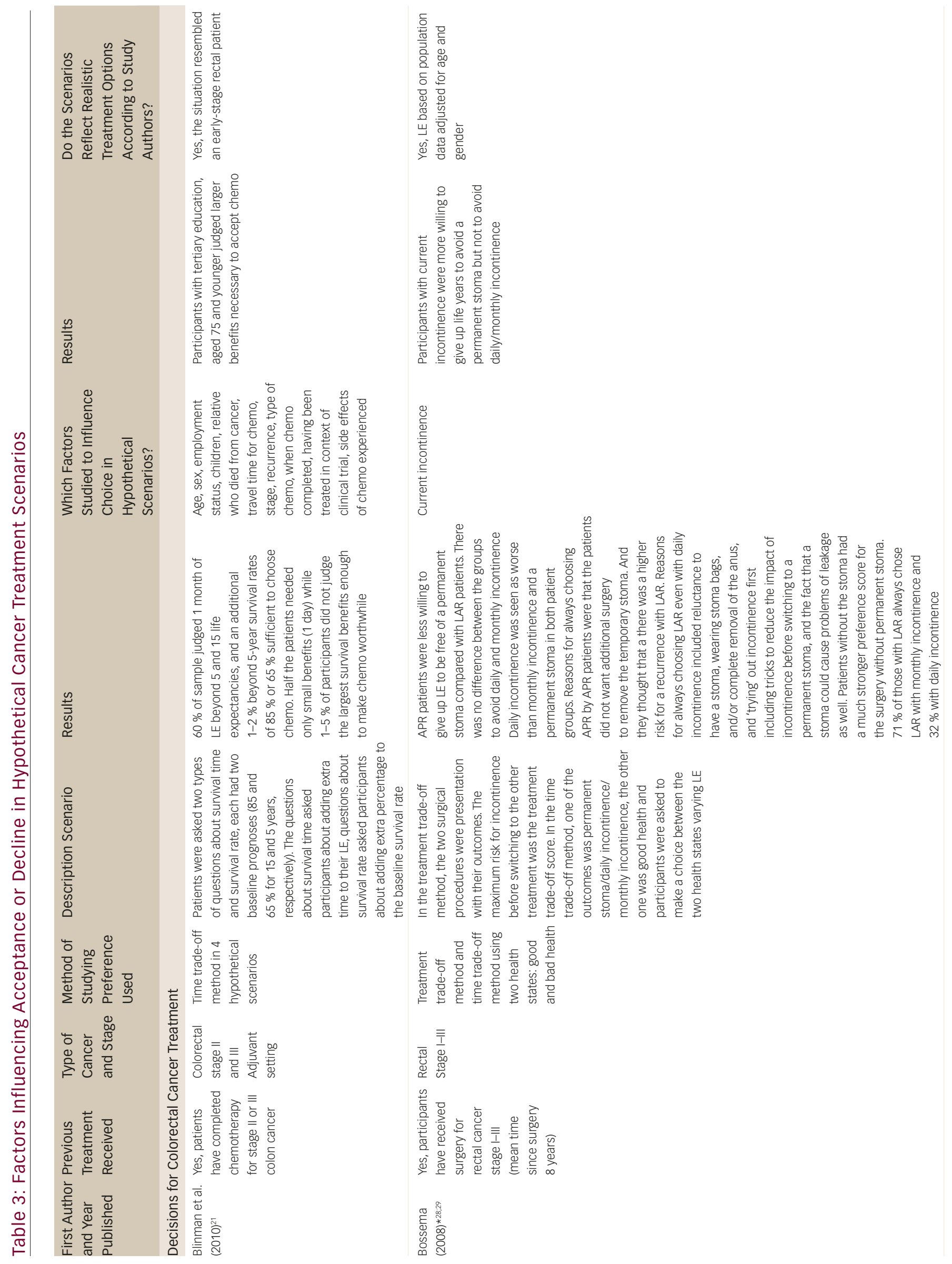




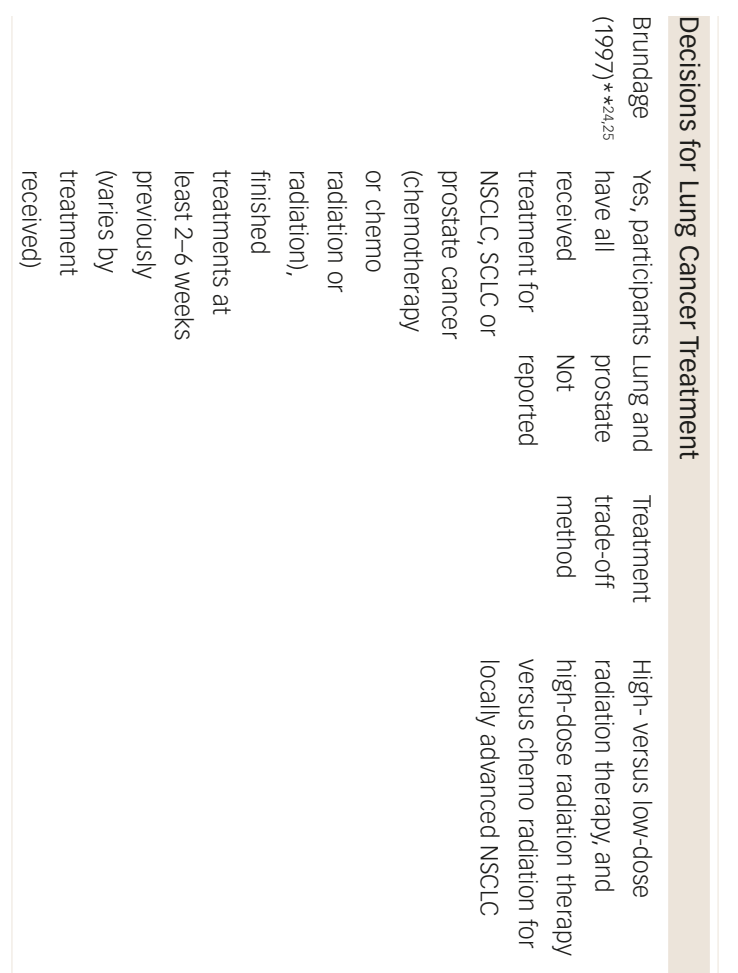

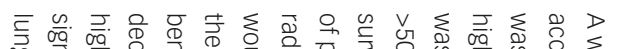

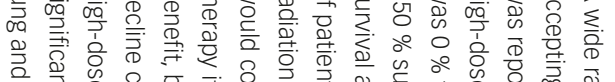

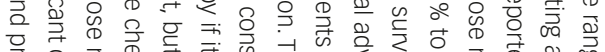

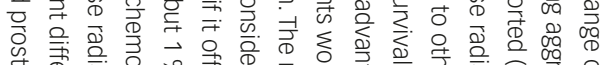

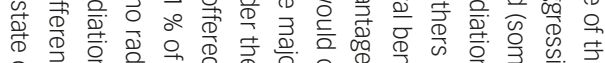

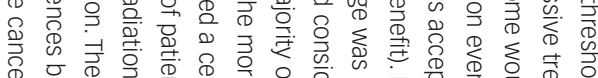

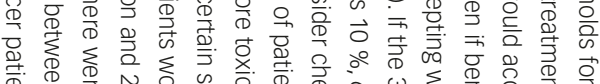

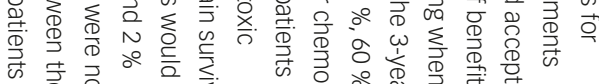



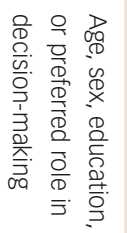

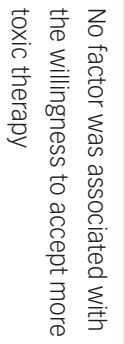

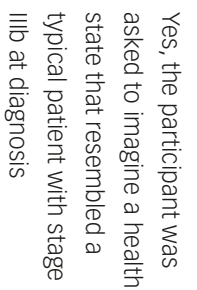

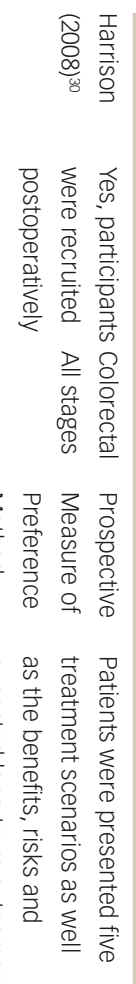



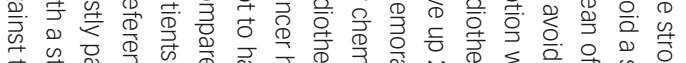

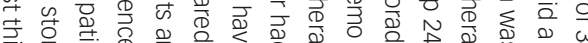

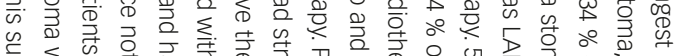

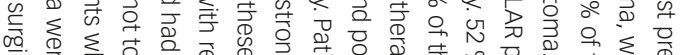

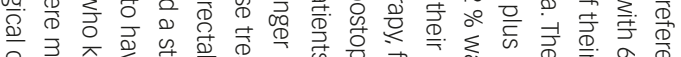

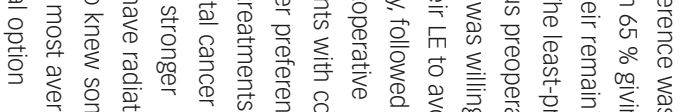

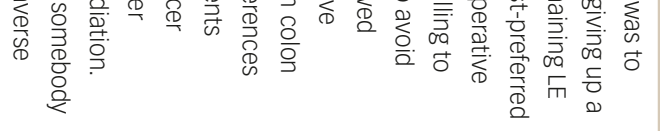
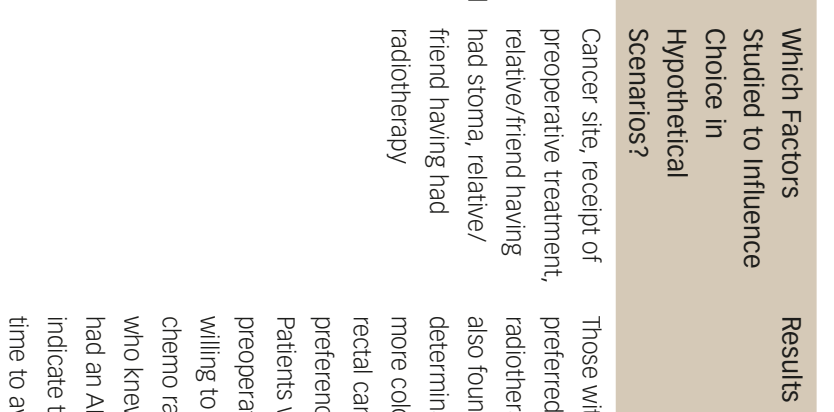

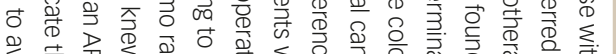

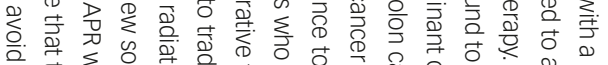

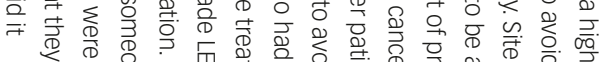

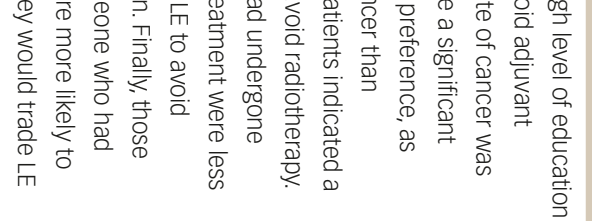

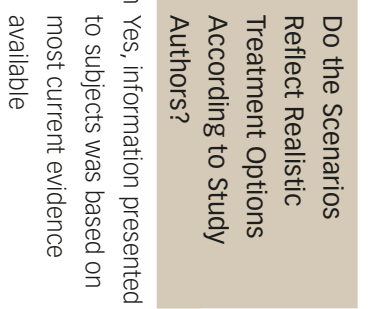





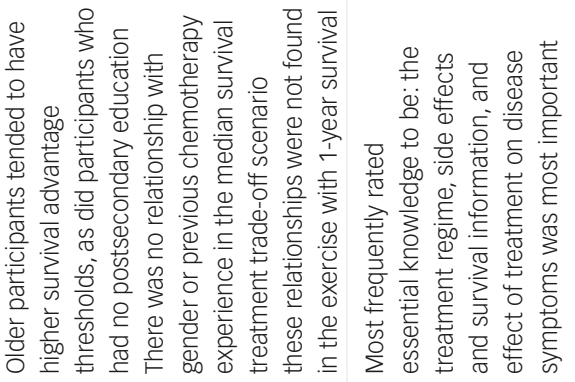


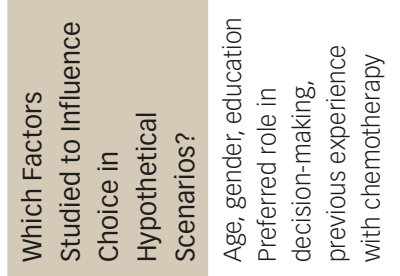

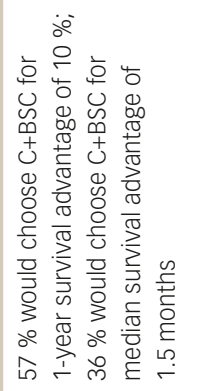

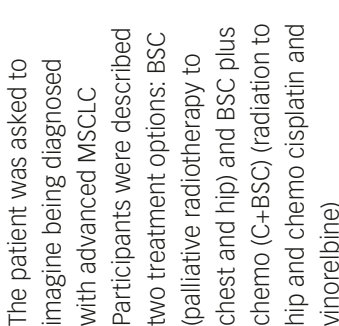



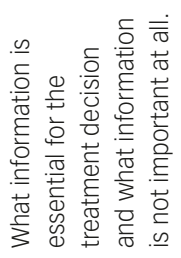



竞



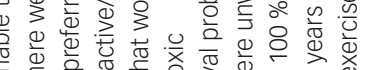
今

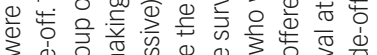

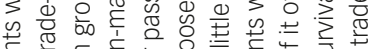

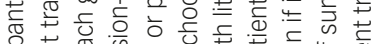

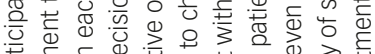

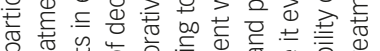

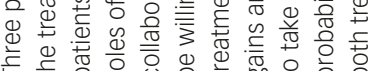

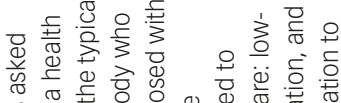



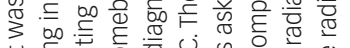


은

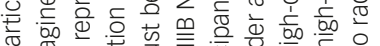



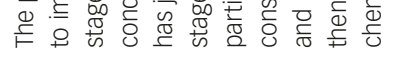

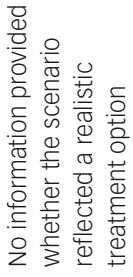

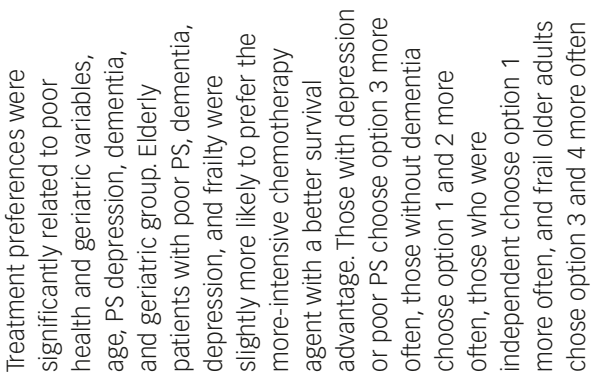



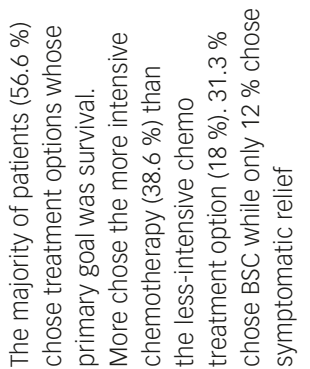

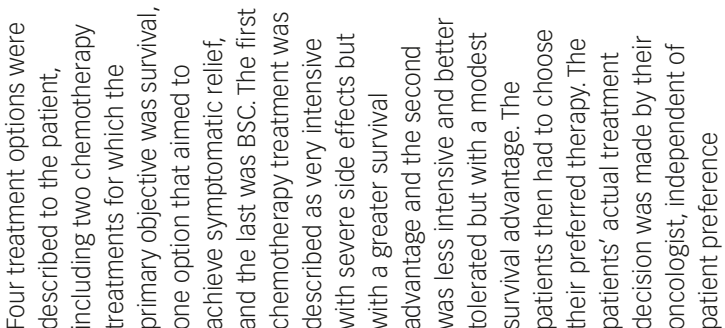

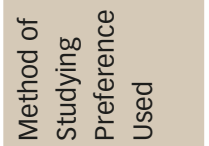

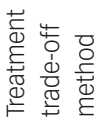

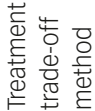

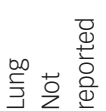

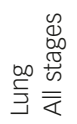

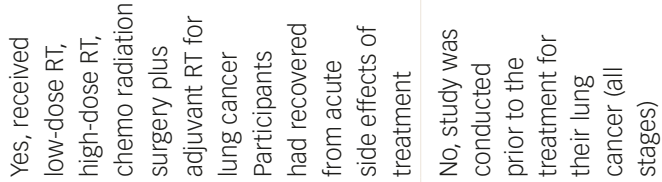






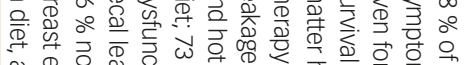

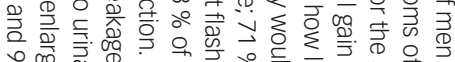

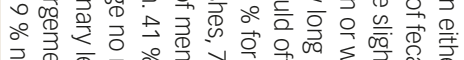



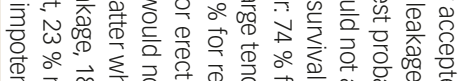



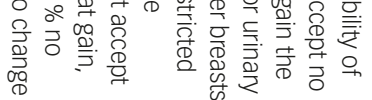
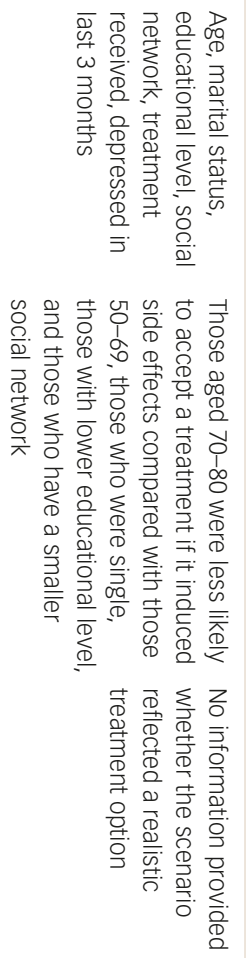
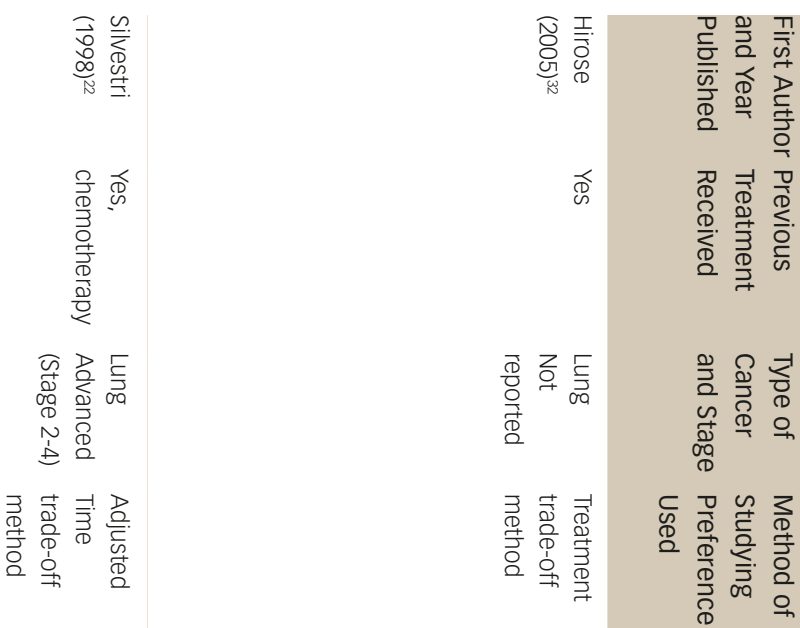

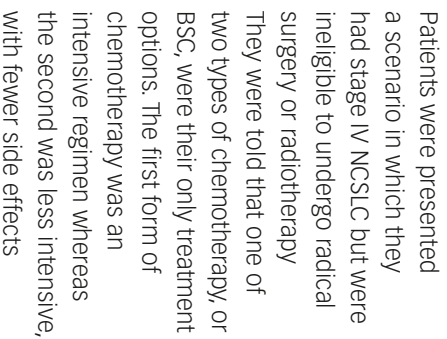

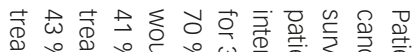

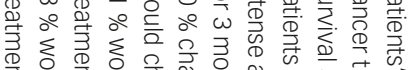

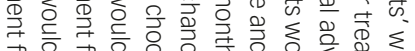

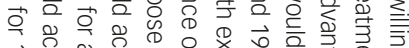

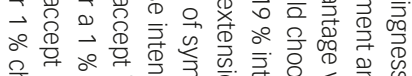

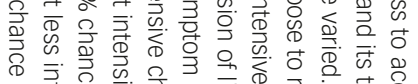

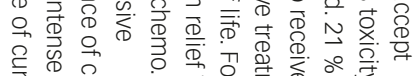



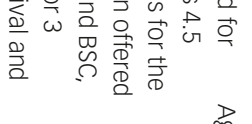
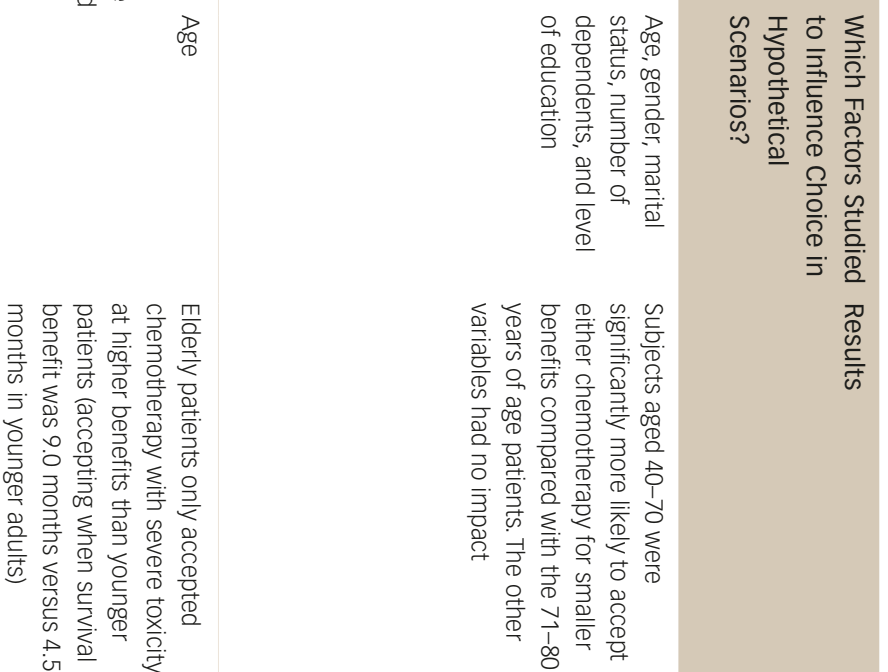

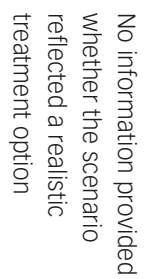



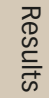

总









Table 4: Summary of Factors Significantly Influencing the Decision to Accept the Treatment Included in the Hypothetical Scenario

\begin{tabular}{|c|c|c|c|c|c|c|c|c|c|}
\hline $\begin{array}{l}\text { First Author } \\
\text { and Year } \\
\text { Published }\end{array}$ & $\begin{array}{l}\text { Decision } \\
\text { Studied }\end{array}$ & Age & Sex & Education & $\begin{array}{l}\text { Marital } \\
\text { Status/Living } \\
\text { Circumstances }\end{array}$ & $\begin{array}{l}\text { Socio- } \\
\text { economic } \\
\text { Circumstances }\end{array}$ & $\begin{array}{l}\text { Previous Treatment } \\
\text { Experience }\end{array}$ & $\begin{array}{l}\text { Health and } \\
\text { Therapy-related } \\
\text { Factors }\end{array}$ & Psychosocial \\
\hline \multicolumn{10}{|c|}{ Colorectal Cancer Decisions } \\
\hline $\begin{array}{l}\text { Blinman et } \\
\text { al.(2010) }{ }^{21} b\end{array}$ & $\begin{array}{l}\text { What survival } \\
\text { benefits would } \\
\text { be worthwhile to } \\
\text { accept adjuvant } \\
\text { chemotherapy }\end{array}$ & $\begin{array}{l}\text { Age less than } \\
75 \text { needed } \\
\text { larger benefits } \\
\text { to accept } \\
\text { treatment }\end{array}$ & NS & $\begin{array}{l}\text { Those with } \\
\text { graduate } \\
\text { education needed } \\
\text { larger benefits to } \\
\text { accept treatment }\end{array}$ & NS & NS & & NS & \\
\hline $\begin{array}{l}\text { Bossema } \\
28,29 * a\end{array}$ & $\begin{array}{l}\text { Willingness } \\
\text { to accept } \\
\text { APR or LAR } \\
\text { against varying } \\
\text { levels of fecal } \\
\text { incontinence or } \\
\text { stoma }\end{array}$ & & & & & & $\begin{array}{l}\text { Previous experience } \\
\text { of living with stoma } \\
\text { or incontinence } \\
\text { influenced the } \\
\text { chance of choosing } \\
\text { APR/LAR }\end{array}$ & $\begin{array}{l}\text { The chance of } \\
\text { incontinence } \\
\text { impacted the } \\
\text { choice }\end{array}$ & \\
\hline $\begin{array}{l}\text { Harrison } \\
(2008)^{30} \mathrm{~b}\end{array}$ & $\begin{array}{l}\text { Willingness to } \\
\text { trade survival } \\
\text { against surgical } \\
\text { and adjuvant } \\
\text { treatment } \\
\text { options }\end{array}$ & & & $\begin{array}{l}\text { Highly educated } \\
\text { persons were } \\
\text { more willing to } \\
\text { trade survival to } \\
\text { avoid RT }\end{array}$ & & & $\begin{array}{l}\text { Patients with pre- } \\
\text { operative treatment } \\
\text { were less likely to } \\
\text { trade survival to } \\
\text { avoid RT } \\
\text { Patients with a friend/ } \\
\text { relative who had an } \\
\text { APR with stoma were } \\
\text { more likely not to } \\
\text { choose this option }\end{array}$ & $\begin{array}{l}\text { Patients with colon } \\
\text { cancer were more } \\
\text { willing to trade } \\
\text { survival to avoid RT }\end{array}$ & \\
\hline \multicolumn{10}{|c|}{ Lung Cancer Decisions } \\
\hline $\begin{array}{l}\text { Brundage } \\
(1997)^{\star *} \\
{ }^{24,25,27} \mathrm{a}\end{array}$ & $\begin{array}{l}\text { Willingness to } \\
\text { trade survival } \\
\text { when making a } \\
\text { choice between } \\
\text { low- and } \\
\text { high-dose RT } \\
\text { and between } \\
\text { high-dose RT and } \\
\text { chemotherapy }\end{array}$ & NS & NS & NS & & & & & \\
\hline $\begin{array}{l}\text { Brundage } \\
(2001)^{26} a\end{array}$ & $\begin{array}{l}\text { Willingness to } \\
\text { trade survival } \\
\text { when making a } \\
\text { choice between } \\
\text { chemotherapy } \\
\text { plus BSC versus } \\
\text { BSC alone }\end{array}$ & $\begin{array}{l}\text { Older patients } \\
\text { required } \\
\text { larger survival } \\
\text { benefits } \\
\text { to accept } \\
\text { treatment }\end{array}$ & NS & $\begin{array}{l}\text { Those with no } \\
\text { lower education } \\
\text { required larger } \\
\text { benefits }\end{array}$ & & & NS & & \\
\hline $\begin{array}{l}\text { Girones } \\
(2012)^{31} a\end{array}$ & $\begin{array}{l}\text { To examine } \\
\text { choice for } 4 \\
\text { lung cancer } \\
\text { treatments } \\
\text { and patient } \\
\text { preferences } \\
\text { and patient } \\
\text { characteristics }\end{array}$ & $\begin{array}{l}\text { Older patients } \\
\text { were more } \\
\text { likely to } \\
\text { choose } \\
\text { aggressive } \\
\text { treatments }\end{array}$ & & & & & & $\begin{array}{l}\text { Poor PS or frailty } \\
\text { more likely to } \\
\text { choose aggressive } \\
\text { treatment }\end{array}$ & $\begin{array}{l}\text { Patients with } \\
\text { depression/ } \\
\text { dementia more } \\
\text { likely to choose } \\
\text { aggressive } \\
\text { treatment }\end{array}$ \\
\hline $\begin{array}{l}\text { Hirose } \\
(2005)^{32} a\end{array}$ & $\begin{array}{l}\text { Willingness to } \\
\text { trade survival, } \\
\text { chemotherapy } \\
\text { response rate } \\
\text { against toxicity } \\
\text { of different } \\
\text { chemotherapy } \\
\text { options }\end{array}$ & $\begin{array}{l}\text { Those }>70 \\
\text { years of age } \\
\text { were less likely } \\
\text { to accept mild } \\
\text { and intense } \\
\text { chemo for } \\
\text { small benefits }\end{array}$ & NS & NS & NS & & & & \\
\hline
\end{tabular}


Geriatric Oncology

Table 4: Cont.

\begin{tabular}{|c|c|c|c|c|c|c|c|c|c|}
\hline $\begin{array}{l}\text { First Author } \\
\text { and Year } \\
\text { Published }\end{array}$ & $\begin{array}{l}\text { Decision } \\
\text { Studied }\end{array}$ & Age & Sex & Education & $\begin{array}{l}\text { Marital } \\
\text { Status/Living } \\
\text { Circumstances }\end{array}$ & $\begin{array}{l}\text { Socio- } \\
\text { economic } \\
\text { Circumstances }\end{array}$ & $\begin{array}{l}\text { Previous Treatment } \\
\text { Experience }\end{array}$ & $\begin{array}{l}\text { Health and } \\
\text { Therapy-related } \\
\text { Factors }\end{array}$ & Psychosocial \\
\hline $\begin{array}{l}\text { Silvestri } \\
(1998)^{22} \mathrm{a}\end{array}$ & $\begin{array}{l}\text { Willingness to } \\
\text { trade survival } \\
\text { when making a } \\
\text { choice between } \\
\text { chemotherapy } \\
\text { with different } \\
\text { toxicity levels } \\
\text { and between } \\
\text { chemotherapy } \\
\text { and BS }\end{array}$ & $\begin{array}{l}\text { Older patients } \\
\text { required } \\
\text { larger survival } \\
\text { benefits } \\
\text { to accept } \\
\text { treatment }\end{array}$ & & & & & $\begin{array}{l}\text { Those who had lower } \\
\text { quality of life during } \\
\text { their treatment } \\
\text { required larger } \\
\text { benefits to accept } \\
\text { treatment }\end{array}$ & & \\
\hline
\end{tabular}

\section{Chemotherapy Decision for Mixed Population}

\begin{tabular}{|c|c|c|c|c|c|c|c|c|}
\hline $\begin{array}{l}\text { Exterman } \\
(2003)^{35} \mathrm{~b}\end{array}$ & $\begin{array}{l}\text { Willingness to } \\
\text { trade survival, } \\
\text { chance of cure } \\
\text { and symptom } \\
\text { relief against } \\
\text { toxicity of } \\
\text { different } \\
\text { chemotherapy } \\
\text { options }\end{array}$ & NS & & & $\begin{array}{l}\text { French patients } \\
\text { were less } \\
\text { likely to accept } \\
\text { treatment than } \\
\text { US patients }\end{array}$ & & $\begin{array}{l}\text { Patients with better } \\
\text { self-rated health are } \\
\text { less likely to reject } \\
\text { mild chemotherapy }\end{array}$ & \\
\hline $\begin{array}{l}\text { Yellen } \\
(1994)^{23} a\end{array}$ & $\begin{array}{l}\text { Willingness to } \\
\text { trade survival } \\
\text { against quality of } \\
\text { life and toxicity } \\
\text { of different } \\
\text { chemotherapy } \\
\text { options }\end{array}$ & $\begin{array}{l}\text { Older patients NS } \\
\text { were less } \\
\text { likely to trade } \\
\text { quality of life } \\
\text { for benefits in } \\
\text { survival }\end{array}$ & & & & $\begin{array}{l}\text { Patients who } \\
\text { previously } \\
\text { experienced } \\
\text { chemotherapy-related } \\
\text { problems chose less- } \\
\text { aggressive treatment }\end{array}$ & NS & \\
\hline \multicolumn{9}{|c|}{ Prostate Cancer Decisions } \\
\hline $\begin{array}{l}\text { Hopfgarten } \\
(2006)^{33} \mathrm{a}\end{array}$ & $\begin{array}{l}\text { Willingness to } \\
\text { trade survival } \\
\text { for freedom of } \\
\text { side effects }\end{array}$ & $\begin{array}{l}\text { Those aged } \\
70-80 \text { were } \\
\text { less likely } \\
\text { to accept } \\
\text { treatment }\end{array}$ & $\begin{array}{l}\text { Those with a } \\
\text { low educational } \\
\text { level were less } \\
\text { likely to accept } \\
\text { treatment }\end{array}$ & $\begin{array}{l}\text { Those who were } \\
\text { single were less } \\
\text { likely to accept } \\
\text { treatment, those } \\
\text { with few friends } \\
\text { were less likely to } \\
\text { accept treatment }\end{array}$ & & NS & $\begin{array}{l}\text { Specific side } \\
\text { effects influence } \\
\text { choice }\end{array}$ & NS \\
\hline $\begin{array}{l}\text { Sculpher } \\
(2004)^{34} a\end{array}$ & $\begin{array}{l}\text { Willingness to } \\
\text { trade survival } \\
\text { against different } \\
\text { side effects of } \\
\text { treatment and } \\
\text { out of pocket } \\
\text { expenses }\end{array}$ & $\begin{array}{l}\text { Older men } \\
\text { were less } \\
\text { influenced by } \\
\text { the ability to } \\
\text { maintain an } \\
\text { erection when } \\
\text { choosing a } \\
\text { treatment }\end{array}$ & & & $\begin{array}{l}\text { The higher } \\
\text { the costs the } \\
\text { less likely the } \\
\text { choice for that } \\
\text { treatment }\end{array}$ & & $\begin{array}{l}\text { The more severe } \\
\text { the side effects the } \\
\text { less likely patients } \\
\text { are to accept that } \\
\text { treatment }\end{array}$ & \\
\hline
\end{tabular}

*Bossema 2008-1 and Bossema 2008-2 report on the same study; **Brundage 1997, Brundage 1998, and Davidson 1999 report on the same study. aVariables tested in univariable analysis only; bVariables tested in multivariable model. For each study, we identified all variables that were examined by study authors. APR = abdominoperineal resection; $B S C=b e s t$ supportive care, $L A R=$ low anterior resection; $N S=$ not significant relationship; $R T=$ radiation therapy; $P S=$ performance status.

mild regimen and 70-77 \% would accept the intensive regimen. Although several potential influential factors were studied, only self-rated health had an impact on the mild chemotherapy decision (those in better selfrated health were less likely to reject the mild chemotherapy regimen). Yellen et al. ${ }^{23}$ reported that 42 patients $>65$ years were less likely to trade quality of life for survival than those $<65$, and that the choice of treatment was related to patient experience with chemotherapy (e.g. those who had experienced problems with the previous treatment were less aggressive). A quarter of patients had been treated prior to the study.

\section{Summary Factors Influencing the Decision to Accept the Treatment}

Table 4 summarizes all factors influencing the decision to accept treatment. With regard to our research question, if older adults' decisions varied by cancer stage, cancer type, cancer treatment, and age, there are mixed results. There are conflicting findings for the influence of age, education, marital status, and previous treatment experience; in some studies, these factors led to increased likelihood of treatment acceptance whereas in other studies it decreased the likelihood of accepting treatment. Only one 
Table 5: Minimum Increase in Survival Rate and Life Expectancy that Participants Considered Worthwhile

\begin{tabular}{|c|c|c|c|c|c|c|c|c|}
\hline \multirow{2}{*}{$\begin{array}{l}\text { First Author } \\
\text { and Year } \\
\text { Published }\end{array}$} & \multicolumn{3}{|c|}{ Minimum Increase in Survival Rate } & \multicolumn{5}{|c|}{ Minimum Increase in Life Expectancy } \\
\hline & $\begin{array}{l}\text { 5-year Survival Rate } \\
\text { Without Treatment }\end{array}$ & $\begin{array}{l}\text { Median } \\
\text { Desired } \\
\text { Increase } \\
(\%)\end{array}$ & $\begin{array}{l}\text { Range } \\
\text { (\%) }\end{array}$ & $\begin{array}{l}\text { Participants } \\
\text { Unwilling to } \\
\text { Accept } \\
\text { Treatment (\%) }\end{array}$ & $\begin{array}{l}\text { Life Expectancy Without } \\
\text { Treatment (Years) }\end{array}$ & $\begin{array}{l}\text { Median } \\
\text { Desired } \\
\text { Increase }\end{array}$ & Range & $\begin{array}{l}\text { Participants } \\
\text { Unwilling to } \\
\text { Accept } \\
\text { Treatment (\%) }\end{array}$ \\
\hline \multicolumn{9}{|c|}{ Decisions for Colorectal Cancer } \\
\hline 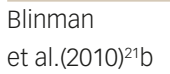 & $65 \%$ & 0.1 & $0.1-35$ & 0 & 5 & 1 month & $\begin{array}{l}1 \text { day- } \\
15 \text { years }\end{array}$ & 0 \\
\hline & $85 \%$ & 0.1 & $0.1-35$ & 0 & 15 & 1 month & $\begin{array}{l}1 \text { day- } \\
15 \text { years }\end{array}$ & 5 \\
\hline \multicolumn{9}{|c|}{ Other Outcomes Studied } \\
\hline \multicolumn{9}{|c|}{ Decisions for Lung Cancer } \\
\hline & Outcome 1 Studied & $\begin{array}{l}\text { Median } \\
\text { Desired } \\
\text { Increase } \\
(\%)\end{array}$ & $\begin{array}{l}\text { Range } \\
(\%)\end{array}$ & $\begin{array}{l}\text { Participants } \\
\text { Unwilling to } \\
\text { Accept } \\
\text { Treatment (\%) }\end{array}$ & Outcome 2 Studied & $\begin{array}{l}\text { Median } \\
\text { Desired } \\
\text { Increase }\end{array}$ & Range & $\begin{array}{l}\text { Participants } \\
\text { Unwilling } \\
\text { to Accept } \\
\text { Treatment (\%) }\end{array}$ \\
\hline \multirow[t]{3}{*}{$\begin{array}{l}\text { Brundage } \\
(1997)^{\star 24,25,27} \mathrm{a}\end{array}$} & $\begin{array}{l}\text { Survival advantage threshold } \\
\text { 6-month endpoint }\end{array}$ & 10 & $3-25$ & 17 & & & & \\
\hline & $\begin{array}{l}\text { Survival advantage threshold } \\
\text { 1-year endpoint }\end{array}$ & 15 & $10-30$ & 9 & & & & \\
\hline & $\begin{array}{l}\text { Survival advantage threshold } \\
\text { 3-year endpoint }\end{array}$ & 10 & $2-30$ & 6 & & & & \\
\hline $\begin{array}{l}\text { Brundage } \\
(2001)^{26} \mathrm{a}\end{array}$ & $\begin{array}{l}\text { 1-year survival advantage } \\
\text { threshold }\end{array}$ & 10 & $43-70$ & NR & $\begin{array}{l}\text { Median survival benefit } \\
\text { threshold }\end{array}$ & 1.5 month & NR & NR \\
\hline \multirow[t]{2}{*}{$\begin{array}{l}\text { Hirose } \\
(2005)^{32 a} a\end{array}$} & $\begin{array}{l}\text { Chance of cure to accept } \\
\text { intensive treatment }\end{array}$ & 10 & NR & NR & $\begin{array}{l}\text { Willingness to accept intensive } \\
\text { chemo threshold }\end{array}$ & 10 months & $0-60$ & $<5 \%$ \\
\hline & $\begin{array}{l}\text { Chance of cure to accept } \\
\text { less-intensive treatment }\end{array}$ & 7 & NR & NR & $\begin{array}{l}\text { Willingness to accept less- } \\
\text { intensive chemo threshold }\end{array}$ & 20 months & $0-60$ & $<5 \%$ \\
\hline \multirow[t]{2}{*}{$\begin{array}{l}\text { Silvestri } \\
(1998)^{22 a}\end{array}$} & & & & & $\begin{array}{l}\text { Willingness to accepted } \\
\text { chemotherapy with mild } \\
\text { toxicity threshold }\end{array}$ & 4.5 months & NR & NR \\
\hline & & & & & $\begin{array}{l}\text { Willingness to accept } \\
\text { chemotherapy with severe } \\
\text { toxicity threshold }\end{array}$ & 9.0 months & NR & $N R$ \\
\hline
\end{tabular}

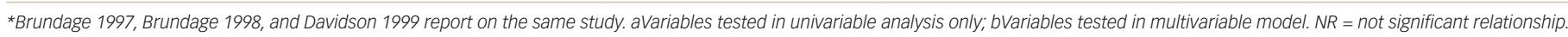

study by Brundage et al. ${ }^{24,25}$ directly compared if the treatment choice varied by cancer type and showed no difference. With regard to differences in preference due to cancer stage, this was not studied. With regard to comparing preferences for the different cancer treatment modalities, most studies examined the preference of older adults for one of two/ three alternative treatments and the type of treatment and potential side effects/toxicity did influence the choice. The findings across all included studies show similar factors to be important, but, as mentioned above, with conflicting findings about the direction of the association. Table 5 shows the results of the willingness to trade survival against different treatment toxicities showing varying willingness to trade survival are described.

\section{Discussion}

To our knowledge, this is the first systematic review focusing on reasons why older adults with cancer accept or decline cancer treatments focusing on studies using hypothetical treatment scenarios. The results showed that the willingness to be treated varied by the benefits of treatment, the particular side effects and previous treatments received/previous treatment experiences. The results also showed conflicting findings in terms of the impact of social status, education, and family situation. None of the reported studies examined the impact of comorbid conditions on treatment preferences but this is be hypothesized to impact older adults' preferences; persons who have been diagnosed with other life-threatening conditions prior to cancer may be less shocked and more experienced in making treatment decisions. In addition, comorbid conditions do impact cancer specialists' treatment recommendations. ${ }^{36-41}$ Only Girones et al..$^{31,42,43}$ reported the level of frailty in the older participants that is common in older adults. Frailty can impact both treatment tolerability and efficacy ${ }^{44-48}$ as well as the treatment delivery, as not all older frail patients will be able to attend a clinic or hospital independently to receive treatment, and thus the general level of frailty of older study participants should be described. As the older population is the most heterogeneous in terms of health and functional status, it is important to have a good assessment of the health and well-being (i.e. geriatric assessment) to inform treatment choices as well as to be able to communicate the potential risks and benefits of treatment, which is crucial for patients' willingness to be treated or not. ${ }^{49}$ In addition, this information will also help the oncologist with developing treatment recommendations. A recent qualitative study of medical oncologists showed considerable variation in treatment recommendations in patients with advanced cancer, and factors such as the physician's 
perception of patient age and life circumstances influenced the treatment recommendation. ${ }^{50} \mathrm{~A}$ geriatric assessment will make the decision based on more objective clinical data and less based on clinical judgments. And with a better estimation of risks and benefits, patients can make more informed choices. A recent systematic review of patients' awareness of disease status did show that this awareness impacted treatment preferences and quality of life. ${ }^{51}$ With the aging of the population, many older patients have more than one chronic condition for which they face treatment decisions. These treatment recommendations may even be conflicting. ${ }^{52-55}$ Therefore, the discussion about treatment goals is crucial for older adults to make informed treatment decisions. However, a recent report of the Institute of Medicine Delivering High-Quality Cancer Care ${ }^{56}$ reported that patients are not always well informed and recommended that patients to be more informed and engaged with the treatment decision-making process as well as more research on older cancer patients and patients with multimorbidities to improve patient centeredness and engagement.

This review showed important gaps in current knowledge. Although we focused on studies with older adults, there were only four studies with a mean age in the seventies (two studies low seventies ${ }^{33,34}$ and two studies mean of 77 years ${ }^{31,35}$ ), and thus little is known about the treatment preferences of the oldest old patients. Similarly, while most studies have focused on lung, colorectal, and prostate cancer, little is known about older adults facing other cancer diagnoses and/or treatments. Furthermore, several of the studies were conducted more than a decade ago. Since then new treatments have been introduced in clinical practice with many of them being oral agents with different risks, benefits, and mode of administration, so it is important to study willingness to be treated with newer, more 'elder-friendly' regimens. Similarly, it is important to study the impact of comorbidities, health literacy, and family support on willingness to be treated and also learn more about the oldest old patients. In addition, it is important to understand how we can support older adults facing cancer treatment decisions who have multimorbidity, as this has not been studied. Lastly, there is little known about the role of the family caregiver in the treatment decision-making process for older adults, while many older adults with cancer are dependent on caregivers for support (e.g. cognitive, emotional, practical, such as transportation, and management of side effects) and thus their role on treatment decision-making should be included in future studies.

This systematic review has several strengths. First, a systematic approach to appraise the literature was used with two independent reviewers reviewing the abstracts and manuscripts and abstracting data. Second, our search was very inclusive as we conducted the search in 10 electronic databases and articles published in four languages. Third, we were comprehensive, no study was excluded based on the quality assessment score and studies using both qualitative and quantitative studies were eligible; however, only studies using a quantitative design were found. However, many studies had a response rate below $60 \%$ or it was not reported, thus there may be selection bias that influences the results of these studies. Furthermore, this review also has limitations. As in any review, the findings are limited by the methodologic quality of the included studies and as many studies were reported a while ago when reporting standards were less clear, there was missing information on response rates and sampling strategies used. Even though we tried to contact all study authors using multiple attempts and using the internet to find current contact information, we were not able to contact all authors and obtain all missing methodological details of the included studies. Last, the studies were too heterogeneous to conduct a meta-analysis.

In conclusion, treatment preferences are influenced by age, social support, potential benefits and risks, and previous treatment experiences. More research is needed to study treatment preferences taking into account multimorbidity, including the oldest old populations, and examining willingness to be treated with newer treatments such as oral agents and/ or targeted agents.
1. Smith $B D$, Smith $G L$, Hurria $A$, et al., Future of cancer incidence in the United States: burdens upon an aging, changing nation, J Clin Oncol, 2009:27:2758-65.

2. Howlader N, Noone AM, Krapcho M, et al., SEER Cancer Statistics Review, 1975-2009, Bethesda: National Cancer Institute, 2012

3. Hori A, Shibata T, Kami M, et al., Age disparity between a cance population and participants in clinical trials submitted as a new drug application of anticancer drugs in Japan, Cancer, 2007;15109:2541-6.

4. Baquet $\mathrm{CR}$, Ellison GL, Mishra SI, Analysis of Maryland cancer patient participation in National Cancer Institute-supported cancer treatment clinical trials, J Clin Oncol, 2008;26:3380-86.

5. El-Rayes BF, Jasti P, Severson RK, et al., Impact of race, age, and socioeconomic status on participation in pancreatic cancer clinical trials, Pancreas, 2010;39:967-71.

6. Scher KS, Hurria A, Under-representation of older adults in cancer registration trials: known problem, little progress, I Clin Oncol, 2012;30:2036-8.

7. Elting LS, Cooksley C, Bekele BN, et al., Generalizability of cancer clinical trial results: prognostic differences between participants and nonparticipants, Cancer, 2006;106:2452-8.

8. Verkooijen HM, Fioretta GM, Rapiti E, et al., Patients' refusal of surgery strongly impairs breast cancer survival, Ann Surg. 2005:242:276-80.

9. Van Leeuwen BL, Rosenkranz KM, Feng LL, et al., The effect of under-treatment of breast cancer in women 80 years of age and older, Crit Rev Oncol Hematol, 2011:79:315-20.

10. Bouchardy C, Rapiti E, Blagojevic S, et al., Older female cancer patients: importance, causes, and consequences of undertreatment, J Clin Oncol, 2007;25:1858-69.

11. Chen RC, Carpenter WR, Hendrix LH, et al., Receipt of guideline concordant treatment in elderly prostate cancer patients, Int J Radiat Oncol Biol Phys, 2014;88:332-8.

12. Rocco N, Rispoli C, Pagano G, et al., Undertreatment of breast cancer in the elderly, BMC Surg, 2013;13(Suppl. 2):S26.

13. Weiss A, Noorbaksh A, Tokin C, et al., Hormone receptor- negative breast cancer: undertreatment of patients over 80 , Ann Surg Oncol, 2013:20:3274-8.

14. Noon AP, Albertsen $\mathrm{PC}$, Thomas $\mathrm{F}$, et al., competing mortality in patients diagnosed with bladder cancer: evidence of undertreatment in the elderly and female patients, $\mathrm{Br} J \mathrm{Cancer}$, 2013;108:1534-40.

15. Yood MU, Owusu C, Buist DS, et al., Mortality impact of less-than-standard therapy in older breast cancer patients, J Am Coll Surg, 2008;206:66-75.

16. Johnson $\mathrm{M}$, Chemotherapy treatment decision making by professionals and older patients with cancer: a narrative review professionals and older patients with cancer: a

17. Chouliara Z, Kearney N, Stott D, et al., Perceptions of older people with cancer of information, decision making and treatment: a systematic review of selected literature, Ann Oncol, 2004;15:1596-602.

18. Strohschein FJ, Bergman H, Carnevale FA, Loiselle CG, Patient decision making among older individuals with cancer, Qual Health Res, 2011:21:900-26.

19. Blinman P, King M, Norman R, et al., Preferences for cancer treatments: an overview of methods and applications in oncology, Ann Oncol, 2012;23:1104-10.

20. Pace R, Pluye P, Bartlett $G$, et al., Testing the reliability and efficiency of the pilot Mixed Methods Appraisal Tool (MMAT) fo systematic mixed studies review, Int I Nurs Stud, 2012;49:47-53.

21. Blinman P, Duric V, Nowak AK, et al., Adjuvant chemotherapy for early colon cancer: what survival benefits make it worthwhile? Eur J Cancer, 2010:46:1800-7.

22. Silvestri $G$, Pritchard $R$, welch $H G$, Preferences for chemotherapy in patients with advanced non-small cell lung cancer: descriptive study based on scripted interviews, BMJ, 1998;317(7161):771-5

23. Yellen SB, Cella DF, Leslie WT, Age and clinical decision making in oncology patients, J Natl Cancer Inst, 1994:86:1766-70.

24. Brundage MD, Davidson JR, Mackillop WJ, Trading treatment toxicity for survival in locally advanced non-small cell lung cancer, J Clin Oncol, 1997;15:330-40.
25. Brundage MD, Davidson JR, Mackillop WJ, et al., Using a treatment-tradeoff method to elicit preferences for the treatment of locally advanced non-small-cell lung cancer, Med Decis Making 1998:18:256-67.

26. Brundage MD, Feldman-Stewart D, Cosby R, et al., Cancer patients' attitudes toward treatment options for advanced nonsmall cell lung cancer: implications for patient education and decision support, Patient Educ Couns, 2001;45:149-57.

27. Davidson JR, Brundage MD, Feldman-Stewart D, Lung cancer treatment decisions: patients' desires for participation and information, Psychooncology, 1999:8:511-20.

28. Bossema E, Stiggelbout A, Baas-Thijssen M, et al., Patients' preferences for low rectal cancer surgery, Eur J Surg Oncol, 2008;34:42-8.

29. Bossema ER, Marijnen CAM, Baas-Thijssen MCM, et al., Evaluation of the treatment tradeoff method in rectal cancer patients: is surgery preference related to outcome utilities? Med Decis Making, 2008:28:888-98.

30. Harrison JD, Solomon MJ, Young JM, et al., Patient and physician preferences for surgical and adjuvant treatment options for rectal cancer, Arch Surg, 2008;143:389-94.

31. Girones R, Torregrosa D, Gomez-Codina J, et al., Lung cancer chemotherapy decisions in older patients: the role of patient preference and interactions with physicians, Clin Trans/ Oncol, 2012;14:183-9.

32. Hirose T, Horichi N, Ohmori T, et al., Patients preferences in chemotherapy for advanced non-small-cell lung cancer, Intern Med, 2005:44:107-13.

33. Hopfgarten T, Adolfsson J, Henningsohn L, et al., The choice between a therapy-induced long-term symptom and shortened survival due to prostate cancer, Eur Urol, 2006;50:280-9.

34. Sculpher M, Bryan S, Fry P, et al., Patients' preferences for the management of non-metastatic prostate cancer: discrete choice experiment, BMJ (Clinical Research ed), 2004:328(7436):382

35. Extermann M, Albrand $\mathrm{G}$, Chen $\mathrm{H}$, et al., Are older French 
patients as willing as older American patients to undertake chemotherapy?, J Clin Oncol, 2003;21:3214-9.

36. van der Poel MW, Mulder WJ, Ossenkoppele GJ, et al. Comorbidity and treatment decision-making in elderly nonHodgkin's lymphoma patients: a survey among haematologists, Neth J Med, 2014;72:165-9.

37. Chen DY, Uzzo RG, Viterbo R, Thinking beyond surgery in the management of renal cell carcinoma: the risk to die from renal cell carcinoma and competing risks of death, World J Urol, 2014;32:607-13

38. Froehner $\mathrm{M}$, Kellner $\mathrm{AE}$, Koch $\mathrm{R}$, et al., A combined index to classify prognostic comorbidity in candidates for radical prostatectomy, BMC Urol, 2014;14:28.

39. Hurria A, Naeim A, Elkin E, et al., Adjuvant treatment recommendations in older women with breast cancer: a survey of oncologists, Crit Rev Oncol Hematol, 2007;61:255-60.

40. Hurria A, Wong FL, Villaluna D, et al., Role of age and health in treatment recommendations for older adults with breast cancer: the perspective of oncologists and primary care providers, J Clin Oncol, 2008;26:5386-92.

41. Wan-Chow-Wah D, Monette J, Monette M, et al., Difficulties in decision making regarding chemotherapy for older cancer patients: A census of cancer physicians, Crit Rev Oncol Hematol, 2011;78:45-58.

42. Krzyzanowska MK, Regan MM, Powell M, et al., Impact of patient age and comorbidity on surgeon versus oncologist preferences for adjuvant chemotherapy for stage III colon cancer, J Am Coll Surg, 2009;208:202-9.

43. Lee L, Cheung WY, Atkinson E, Krzyzanowska MK, Impact of comorbidity on chemotherapy use and outcomes in solid tumors: a systematic reviow, J Clin Oncol, 2011:29:106-17.

44. Audisio RA, van Leeuwen $L B$, When reporting on older patients with cancer, frailty information is needed, Ann surg Oncol, 2011;18:4-5.

45. Baijal $P$, Periyakoil V, Understanding frailty in cancer patients, Cancer J, 2014;20:358-66.

46. Balducci L, Aging, frailty, and chemotherapy, Cancer Control, 2007:14:7-12.

47. Ferrucci L, Guralnik JM, Cavazzini C, et al., The frailty syndrome: a critical issue in geriatric oncology, Crit Rev Oncol Hematol, 2003;46:127-37.

48. Hamaker ME, Jonker JM, de Rooij SE, et al., Frailty screening methods for predicting outcome of a comprehensive geriatric assessment in elderly patients with cancer: a systematic review, Lancet Oncol, 2012;13:e437-e444.

49. Wildiers $\mathrm{H}$, Heeren P, Puts $\mathrm{M}$, et al., International Society of Geriatric Oncology Consensus on Geriatric Assessment in Older Patients With Cancer, I Clin Oncol, 2014;32:2595-603

50. Schildmann J, Tan J, Salloch S, Vollmann J, "Well, I think there is great variation...": a qualitative study of oncologists' experiences and views regarding medical criteria and other factors relevant to treatment decisions in advanced cancer Oncologist, 2013;18:90-6.

51. Finlayson CS, Chen YT, Fu MR, The impact of patients' awareness of disease status on treatment preferences and quality of life among patients with metastatic cancer: a systematic review from 1997-2014. J Palliat Med, 2015;18:176-86

52. Markun S, Holzer BM, Rodak R, et al., Therapeutic conflicts in emergency department patients with multimorbidity: a crosssectional study, PLOS One, 2014;9:e110309.

53. Rocca WA, Boyd CM, Grossardt BR, et al., Prevalence of multimorbidity in a geographically defined american population: patterns by age, sex, and race/ethnicity, Mayo Clin Proc, 2014;89:1336-49

54. Violan C, Foguet-Boreu Q Flores-Mateo G, et al., Prevalence, determinants and patterns of multimorbidity in primary care: a systematic review of observational studies, PLOS One 2014;9:e102149.

55. Ritchie CS, Kvale E, Fisch MJ, Multimorbidity: an issue of growing importance for oncologists, J Oncol Pract, 2011;7:371-4.

56. Institute of Medicine, Delivering high-quality cancer care. Charting a new course for a system in crisis committee on improving the quality of cancer care: addressing the challenges of an aging population, Washington, DC, The National Academies Press, 2013 